\title{
'To the benefit of Africa, the world, and ourselves': The American Negro Leadership Conference on Africa (ANLCA) Mission to Nigeria, 1966-1968 - CORRIGENDUM
}

James Austin Farquharson

doi:10.1017/S1740022821000292, Published online by Cambridge University Press, 24 September 2021.

Keywords: African American; Nigeria; Biafra; Black Internationalism; Civil War

This article published online with some textual errors that are corrected below:-

Page 4 Footnote 14 should read '..${ }^{14}$ See Bayard Rustin, "How Black Americans see Black Africa - and vice versa", in Time of Two Crosses: The Collected Writings of Bayard Rustin, eds., Devon W. Carbado and Donald Weise (San Francisco: Cleis Press Inc, 2003), 314-317; John A. Davis, "Black Americans and United States Policy towards Africa", Journal of International Affairs 23, No. 2 (1969), 242-243; Plummer, In Search of Power, 199; Roy M. Melbourne, "The American Response to the Nigerian conflict, 1968", Issue: A Journal of Opinion 3, No. 2 (1973), 39; Heerten, The Biafran War, 239; Martin Staniland, American Intellectuals and African Nationalists, 1955-1970 (New Haven: Yale University Press, 1991), 204-209.'

Page 5 Under the heading 'The ANLCA, post-colonial Africa and Nigeria in turmoil', a part of the Footnote 14 text was incorrectly inserted in the middle of the quote. The quote should read:-

when the intensity of our own problems excluded our awareness of the existence of injustice anywhere as a threat to justice everywhere. Colonialism and segregation are nearly synonymous....

In many ways the future of the emergent African nations and the American Negro are intertwined. As long as segregation and discrimination exist in our nation, the longer the chances of survival are for colonialism and vice-versa. ${ }^{19}$

\section{Reference}

James Austin Farquharson, “To the benefit of Africa, the world, and ourselves': The American Negro Leadership Conference on Africa (ANLCA) Mission to Nigeria, 1966-1968', Journal of Global History, Published online 24 September 2021, doi: $10.1017 /$ S1740022821000292.

Cite this article: Farquharson JA. 2022. 'To the benefit of Africa, the world, and ourselves': The American Negro Leadership Conference on Africa (ANLCA) Mission to Nigeria, 1966-1968 - CORRIGENDUM. Journal of Global History 17: 562, doi:10.1017/S1740022821000395 